\title{
The Effect of Corncob (Zea mays) Extract Cream on the Number of Melanin Pigments of Guinea Pig Exposed to Ultraviolet
}

\author{
Pasid Harlisa $^{1}$, Sita Mahardhika ${ }^{2}$, Suryani Yuliyanti ${ }^{3}$ \\ ${ }^{1}$ Department of Dermatology and Venereology Medical Faculty Sultan Agung Islamic University \\ ${ }^{2}$ Student of Medical Faculty Sultan Agung Islamic University \\ ${ }^{3}$ Department of Public Health Medical Faculty Sultan Agung Islamic University
}

\begin{abstract}
Background: Exposure to Ultraviolet B (UVB) rays on the skin causes many problems, including pigmentation and aging effect. Hence, protection against it is needed. Purpose: The study aimed to determine the effect of corn cob extract cream on the number of melanin pigments in guinea pig skins exposed to UVB rays. Methods: An experimental post-test-only control group study was conducted on the 25 guinea pigs. The guinea pigs were divided randomly into five groups: group I without cream, group II cream base, group III hydroquinone cream, group IV $30 \%$ corncob extract cream, and group V $40 \%$ corncob extract cream. The cream was given daily for 20 minutes before UVB exposure and 4 hours after UVB exposure. The total dose of UVB exposure was $780 \mathrm{~mJ} / \mathrm{cm}^{2}$ for 28 days. The amount of melanin pigment was calculated using the CX21 image J. Result: The number of melanin pigment in groups I, II, III, IV, and V were $22.8 \pm 0.4$ cells, $18 \pm 0.3$ cells, $6.3 \pm 3.1$ cells, $13.8 \pm 0.2$ cells, and $9.4 \pm 0.5$ cells, respectively. A significantly different value of One way ANOVA test was $<0.05$. Thus, there was a difference in the number of melanin pigments between the five groups. LSD post-hoc test showed differences in each group ( $\mathrm{p}<0.05$ ). Conclusion: $40 \%$ corn cobs extract cream effectively decreased the number of melanin pigment in guinea pigs exposed to UVB rays.
\end{abstract}

Keywords: corn cob extract cream, melanin pigment, UVB.

Correspondence: Suryani Yuliyanti, Faculty of medicine Universitas Islam Sultan Agung, Jl Kaligawe Raya Km 4 Semarang, Indonesia, suryaniyuliyanti@unissula.ac.id, +628156566797.

Article info | Submited: 10-8-2021, Accepted: 9-9-2021, Published: 30-11-2021

\section{BACKGROUND}

Melanocyte cells produce melanin pigment to protect the skin against ultraviolet radiation, and it is called melanogenesis. ${ }^{1}$ Melanin production depends on the intensity of sunlight exposure. More exposure to a higher ultraviolet (UV) index would result in a higher amount of melanin production. ${ }^{2}$ Extended sun exposure can cause skin pigmentation to skin cancer. ${ }^{1}$ This condition corresponds with Indonesia's geography, a tropical country with an overabundance of UVB exposure.

There have been efforts to manage skin aging, especially in skin pigmentation, such as applying photoprotector, topical medicines containing retinoic acid or hydroquinone, and more aggressive therapy such as chemical peeling, microdermabrasion, botulinum toxin injection, filler injection, and laser therapy that can have side effects to the body. ${ }^{3}$

Not many people pays attention to the photoprotective effect of corn cob extract. It contains an active substance, namely phenolic, that can block free radicals. Therefore, it has antioxidant properties. ${ }^{4}$ UVB rays trigger Reactive Oxygen Species (ROS) production on keratinocyte and melanocyte membranes, especially during the lipid peroxidation. The melanogenesis process triggered by an increase in ROS $^{1}$ can be inhibited by active ingredients in the form of flavonoids. It stabilizes reactive free radicals so that skin damage can be avoided. ${ }^{5}$ Studies on the effect of corncob extract on the number of melanin pigments in guinea pigs exposed to UVB light are still limited. Hence, further exploration is needed.

A study revealed that around $42 \%$ of females and $72 \%$ of males experience photoaging (skin aging) is under 30 years, and it has increased in the last few decades. $^{3}$ Melasma is one of the types of skin hyperpigmentation. Melasma in Asia is often diagnosed and yield $0.25-4 \%$. Melasma is common in dark-skinned people, especially in East, West, and Southeast Asia, Hispanic, and black-skinned people who live in an area with high sun exposure. Melasma is a chronic and often exacerbated condition. It can also cause a negative psychosocial impact for the patients. ${ }^{6}$

Corncob is an excess waste collected from corn. It contributes to being estimated around $40-50 \%$ of corn weight. ${ }^{7}$ Corncob waste is widely available in Indonesia. Corncob is a local potential phenolic active 
compound that can be used as free radical prophylaxis. $^{8}$ The flavonoids in the cream act as antioxidants by neutralizing reactive free radicals into a relatively stable unreactive form. ${ }^{5}$ Saleh et al. reported that corn cob extract at a concentration of $40 \%$ has a phenolic total up to $81.53 \mathrm{mg} / \mathrm{kg}$, and it has been proven to have a role in blocking free radicals. Phenol and flavonoid have both been confirmed to have antioxidant activities. Guo, J. et al. in 2009 reported that corncob and corn hair extract contains quercetin compound that may act as a blockade for UV-induced free radicals. ${ }^{9}$

Corncob may function as a source of antioxidant agents. Corncob contains flavonoid compounds that serve as a free radical barrier. ${ }^{10}$ Exposure to UVB increases the ROS, and it will signal the body to regulate mRNA tyrosinase for producing melanin. ${ }^{11}$ Free radical neutralizing mechanism by antioxidant is achieved through hydrogen atom donation so that free radical became more stable. ROS will not be formed; therefore, no increase in the amount of melanin pigment. ${ }^{10}$ This study aimed to evaluate the effect of corncob extract on the number of melanin pigments in guinea pigs exposed to UVB light.

\section{METHODS}

This was an experimental study involving test animals in the laboratory. The study design was a post-test-only control group design. Treatment of test animals was done in Balai Besar Veteriner Wates Yogjakarta for 28 days. The sample size was calculated using the Federer formula, and the number of test animals in each group was 5. Treatment was done on 25 guinea pigs which were randomized and sorted into 5 groups; group I without cream, group II basic cream, group III hydroquinone cream, group IV $30 \%$ corncob extract cream, and group V 40\% corncob extract cream. This research used corncob obtained from Ungaran, Semarang Regency. The corncob extract was obtained using the maceration method with $70 \%$ ethanol solvent. ${ }^{4}$ Before being treated, the guinea pigs were adapted for seven days. The cream was given daily for 20 minutes before the UVB exposure and 4 hours after UVB exposure. Exposure to UVB rays was done every Monday, Wednesday, and Friday with a daily dose of $65 \mathrm{~mJ} / \mathrm{cm}^{2}$. A total of $12 \mathrm{UVB}$ rays were irradiated with a total dose of $780 \mathrm{~mJ} / \mathrm{cm}^{2}$ for 28 days.

The doses of corncob extract cream used were $30 \%$ and $40 \%$. The dosage refers to the previous research, which states that corncob extract at a dose of $40 \%$ contains high phenolic, namely $81.53 \mathrm{mg} / \mathrm{kg}$, which has potential as an antioxidant. It has a good ability as an antidote to free radicals. The dose of $30 \%$ was set as a comparison because, in previous studies, it was stated that the corncob extract at a dose of $20 \%$ has low phenolic content. ${ }^{8}$

After completing the treatment, all guinea pigs were rested for 24 hours, and then the euthanasia proceeded. The back skin tissue was taken and put in a $10 \%$ formalin solution. Histological preparations of guinea pig's skin tissue were made to examine the melanin pigment. It was done at the Anatomical Pathology Laboratory of RSISA Semarang. The melanin pigment was calculated using the digital analysis with Masson-Fontana stain. Each preparation was photographed using an Optilab Pro camera and an Olympus CX21 microscope (a tool used to observe microscopic objects). The Olympus CX21 microscope can observe in a simple, practical, effective, and targeted manner. The microscope is equipped with $\mathrm{AV}$ and USB connectors so that observations can be made by recording, such as moving objects or images into a laptop or PC. The object was observed using the microscope at a 400x magnification. Each preparation was photographed five times and saved in JPEG format. The calculation of the number of melanin pigment was carried out using the Adobe Photoshop CS3 version 10.01. The collected data were then analyzed statistically with One Way Anova. Furthermore, a post-hoc least significant difference (LSD) test was carried out to discover which group is significantly different $(p<0.05)$. This study has been approved by the Ethics Committee FK UNISSULA No. 375/XI/2020/Komisi Bioetik.

\section{RESULT}

Animals test were treated in the Balai Besar Veteriner Wates Yogjakarta for 28 days in December 2020. Treatment was given to 25 guinea pigs taken using simple random sampling methods and divided into 5 groups where each group consisted of 5 guinea pigs. The group I or negative control group did not receive any treatment with any cream, group II received basic cream, group III or positive control received hydroquinone cream, the group IV and $\mathrm{V}$ received corncob extract $30 \%$ and $40 \%$, respectively. There was no dropout in this research. This research aimed to discover the effect of corncob extract cream on the number of melanin pigment in the skin of guinea pigs exposed to UVB.

The number of melanin pigment in the skin was assessed through histopathological examination using a microscope at a 400x magnification in 5 fields of view. The result is shown in Figure 1.

Figure 1 exhibits melanocytes observed in each group. Figure A, B, C, D, and E displayed microscopic pictures from each group, the group I 
negative control, group II basic cream, group III hydroquinone, group IV $30 \%$ corncob extract, and group V 40\% corncob extract.

From the figure above, group I (negative control group) has the highest amount of melanocytes. The number of melanocytes in group II (basic cream group) was slightly lower than group I. Compared the group I and II, the number of melanocytes in group II and IV was slightly lower. The lowest amount of melanocyte was observed in group V, 40\% corncob extract.

The average melanocyte amount of the skin in each group is depicted in Figure 2.
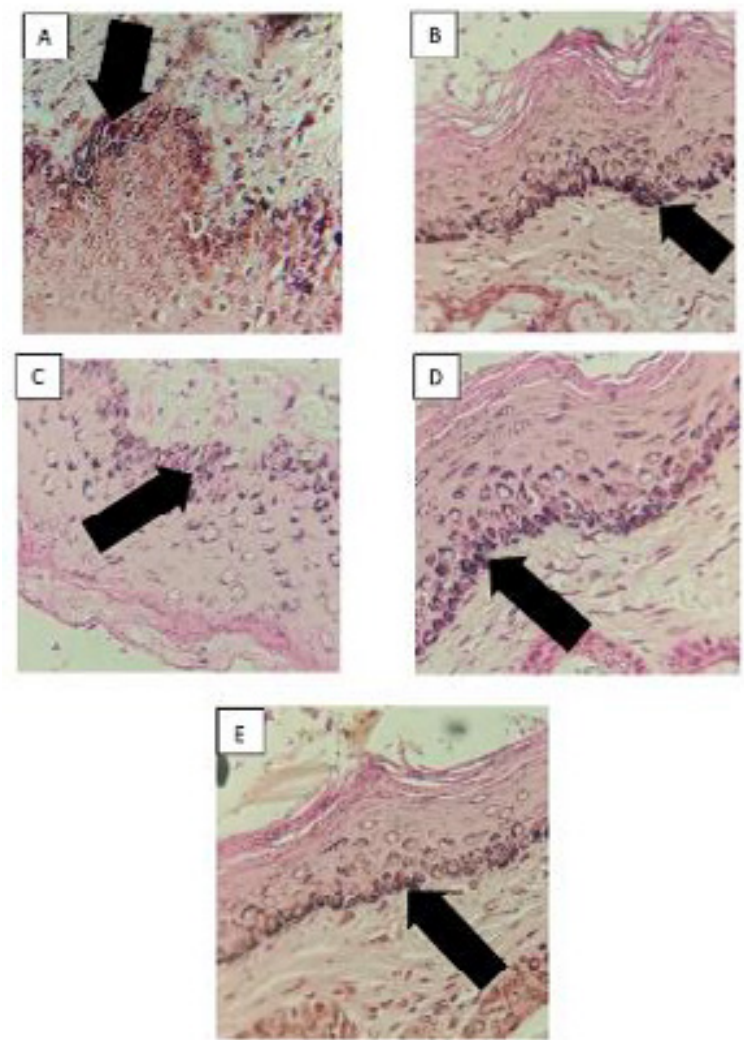

Figure 1. An image of the amount of melanin in the skin was taken through histopathology examination in Anatomic Pathology Laboratory RSISA Semarang for two weeks in January 2021.

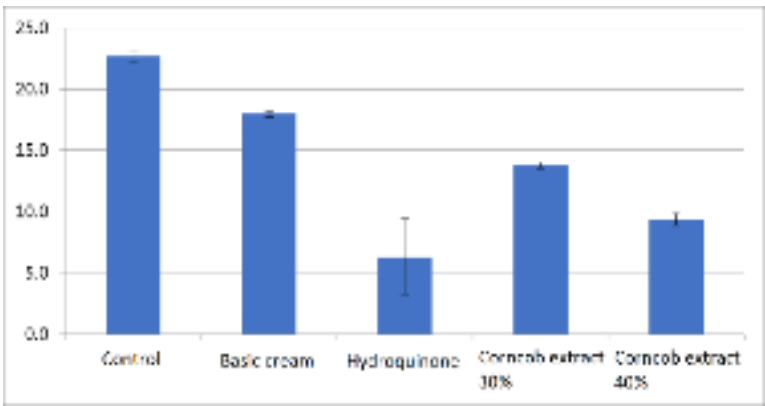

Figure 2. Mean melanocyte amount.

Figure 2 shows the average melanocyte count from each group on day 28. From this graph, the hydroquinone group has the lowest amount of melanin $(6.3 \pm 3.1$ cells $)$. Meanwhile, the negative control group has the highest amount of melanin (22.8 \pm 0.4 cells).

The average number of skin melanocytes in these 5 groups was then analyzed for normality distribution by Shapiro Wilk. The result was significant, with $p>0.05$. Therefore, we concluded that the data were distributed normally in all test groups. The data were analyzed with the Levene-test afterward to evaluate the data homogeneity. We found $p=0.072(p>0.05)$, implying the average count of melanin pigment on the skin is homogenous.

The number of skin melanin pigment data fulfills the requirements for parametric data. Furthermore, hypothesis test using One Way Anova with post hoc tests suitable for equal variances assumed, which is fisher least significant difference (LSD).

Table 1. The results of hypothesis test (p), Shapiro Wilk, Levene Test, and One Way Anova

\begin{tabular}{llll}
\hline \multicolumn{1}{c}{ Group } & $\begin{array}{l}\text { Shapiro- } \\
\text { Wilk test }\end{array}$ & $\begin{array}{l}\text { Levene } \\
\text { Test }\end{array}$ & $\begin{array}{l}\text { One way } \\
\text { Annova } \\
\text { test }\end{array}$ \\
\hline $\begin{array}{l}\text { Negative control } \\
\text { Basic cream }\end{array}$ & 0.377 & 0.072 & 0.001 \\
$\begin{array}{l}\text { Hydroquinone } \\
\text { 30\% corncob extract } \\
\text { creamx }\end{array}$ & 0.325 & & \\
$40 \%$ corncob extract & 0.146 & \\
cream & 0.105 & & \\
\hline
\end{tabular}

As revealed in table 1, the One Way Anova test result was $p=0.001 \quad(p<0.05)$, indicating the research hypothesis was accepted. This means that the corncob extract affects the number of melanin pigments of the skin. This result points out a significant change in the average number of melanin pigment between the 5 groups. The post hoc least significant difference (LSD) test was to identify group pair that showed significant differences. The result is depicted in Table 2.

Table 2. Result of post hoc least significant difference (LSD)

\begin{tabular}{|c|c|c|c|c|c|}
\hline Group & Control & Basic & $\begin{array}{l}\text { Hydroquin } \\
\text { one }\end{array}$ & $\begin{array}{l}30 \% \\
\text { cornco } \\
b \\
\text { extract }\end{array}$ & $\begin{array}{l}40 \% \\
\text { cornco } \\
\text { b } \\
\text { extract }\end{array}$ \\
\hline Control & & $0.000 *$ & $0.000^{*}$ & $0.000 *$ & $0.000^{*}$ \\
\hline Basic & $0.000 *$ & & $0.000^{*}$ & $0.000^{*}$ & $0.000 *$ \\
\hline $\begin{array}{l}\text { Hydroquinon } \\
\mathrm{e}\end{array}$ & $0.000 *$ & $0.000 *$ & & $0.000^{*}$ & $0.000^{*}$ \\
\hline $\begin{array}{l}30 \% \text { corncob } \\
\text { extract }\end{array}$ & $0.000^{*}$ & $0.000 *$ & $0.000^{*}$ & & $0.000 *$ \\
\hline $\begin{array}{l}40 \% \text { corncob } \\
\text { extract }\end{array}$ & $0.000 *$ & $0.000 *$ & $0.000^{*}$ & $0.000^{*}$ & \\
\hline
\end{tabular}

Notes: ${ }^{*}(p<0.05)$ significant difference 
The result shows a significant difference $(p<0.05)$ on all test groups. In addition, the amount of melanin pigment in basic cream, hydroquinone, $30 \%$ corncob extract, and $40 \%$ corncob extract groups differ significantly from the negative control group.

\section{DISCUSSION}

Based on the statistical analysis of the average number of melanin pigments of the skin, there was a significant difference between groups with exposure to UVB, basic cream, hydroquinone, $30 \%$ corncob extract, and $40 \%$ corncob extract $(p<0.05)$. This study also confirms that treatment using corncob extract with $30 \%$ or $40 \%$ concentration will reduce the number of skin melanin pigments. This is because corn cob has antioxidant properties. Flavonoid contained in corn cob also has a protective effect against UVB. It works by inhibiting and neutralizing ROS production. These processes inhibit melanin production. ${ }^{10}$

There was no protective agent against free radical in the negative control group, resulting in a significant difference in the amount of melanin pigment between the negative control and other groups. This is in line with the theory stating that overexposure to UVB promotes melanin production. ${ }^{12}$ UV light exposure affects the $\mathrm{p} 53$ protein that acts as the expression and activity of tyrosinase and Tyrp 1 . The p53 sequence in the proopiomelanocortin promoter (POMC) binds and regulates the expression of this gene. Increased expression of POMC due to the activation of p53 and UV induction, which will then be broken down into small peptides, namely adrenocorticotropic hormone (ACTH), $\alpha-, \beta$ - and Gamma-Melanocyte Stimulating Hormone $(\gamma-\mathrm{MSH})$, Alpha-Melanocyte Stimulating Hormone (A-MSH), will stimulate the melanocortin-1 receptor (MC1R) in melanocytes, increasing melanin production. ${ }^{1}$

UVB exposure to the skin may also influence antioxidants on the skin. Ascorbic acid, glutathione (GSH), superoxide dismutase (SOD), catalase, and ubiquinol are endogenous antioxidants present in all skin layers, and they will diminish due to UVB exposure. ${ }^{13}$ In addition, UVB exposure can induce mutations that will produce ROS, including hydroxyl radicals $(\mathrm{OH})$, hydrogen peroxide $(\mathrm{H} 2 \mathrm{O} 2)$, superoxide anions $(\mathrm{O} 2)$, and nucleotides that are susceptible to ROS. Increased production of ROS in keratinocytes and melanocytes will cause DNA damage and further activate $\mathrm{p} 53$, triggering melanogenesis. ${ }^{1}$

There was no significant difference between the negative control and basic cream groups. This shows that basic cream does not have a protective effect against UV radiation. Overexposure to UV light may trigger acute changes, such as erythema, pigmentation, photosensitivity, and early aging. Basic cream has a $\mathrm{pH}$ of 1 , and a higher $\mathrm{pH}$ value was observed in hydroquinone and corncob extract groups. Higher $\mathrm{pH}$ value contributes to the protective effect of guinea pig's skin. ${ }^{14}$ This theory is the basis of the concentration increase in corncob extract used in this study.

This study exhibits the significant difference in the number of melanin pigment of the skin in the hydroquinone group compared to corncob extract at concentrations of $30 \%$ and $40 \%$. This may be due to the hydroquinone inhibiting melanogenesis, and consequently, acting as a skin lightener. Hydroquinone also inhibits the tyrosinase enzyme; therefore, it blocks conversion from dihydroxyphenylalanine to melanin. ${ }^{15}$ However, long-term use of hydroquinone with a dosage over $2 \%$ can potentially cause ochronosis. $^{16}$ A significant difference of the average number of melanin pigment of the skin between $30 \%$ and $40 \%$ group $(p<0.05)$ shows that $30 \%$ corncob extract cream was not optimal in lowering the melanin number. At a concentration of $40 \%$, corncob extract could inhibit and neutralize ROS production, and it resulted in a lower amount of melanin.

The cream formulation used in this study was a W/O cream composed of water dispersed in oil. This was chosen because it has a stronger penetration and can easily release oil-soluble drugs as oil forms the continuous phase compared to $\mathrm{O} / \mathrm{W}$ cream. ${ }^{18}$ In general, people prefer the $\mathrm{W} / \mathrm{O}$ type, which spreads better; although it is a little oily, the evaporated water can reduce the heat on the skin. The advantage of the $\mathrm{W} / \mathrm{O}$ type is that it has a much longer adhesion when compared to $\mathrm{O} / \mathrm{W}$ cream. ${ }^{18}$ One of the examples of $\mathrm{W} / \mathrm{O}$ type is cold cream which comprises more oil phase. When rubbed on the skin, there is a cooling effect due to slow evaporating water content in the emulsion but fast absorption of the skin. ${ }^{17} 40 \%$ corncob extract has a fewer basic cream content than the $30 \%$ corncob extract, so that it lessened cream penetration into the skin. ${ }^{19}$

The study revealed that $40 \%$ extract of corncob can decrease the amount of melanin in the skin. Therefore, we conclude that the optimum dose to reduce the amount of melanin pigment is $40 \%$ concentration. This result is in line with the previous research. It reported that $40 \%$ extract of corncob has a better ability in neutralizing free radical, parallel to total phenolic compound inside corncob extract. Therefore, $40 \%$ corncob extract is more useful in managing free radical and peroxide radical than $30 \%$ corncob extract. Corncob extract on concentration 
$40 \%$ will effectively inhibit lipid oxidation due to free radicals caused by overexposure to UV light. ${ }^{8,20} \mathrm{We}$ used methanol as the extracting solvent, and it is commonly used for flavonoids with polar compounds in corncob. ${ }^{4}$

The photoprotective role of corncob extract cream is gained from a flavonoid, a phenolic compound that acts as an antioxidant or free radical prophylactic. Flavonoid is composed of many hydroxyl clusters that donate its hydrogen atom to free radical molecules; therefore, it acts as an antioxidant. ${ }^{9}$ Exposure to UVB rays triggers the lipid peroxidase process of keratinocyte and melanocyte membranes to produce ROS. Flavonoid compounds can neutralize radicals originating from UV induction by making reactive free radicals unreactive, which tends to be more stable. Therefore, skin damage caused by free radicals can be overcome. ${ }^{5}$ Flavonoid will function as free radical prophylactic so that ROS will not be formed and melanogenesis process will not occur. Consequently, the melanin amount will not increase. ${ }^{10}$ Quercetin found inside corncob and corn hair extract may act as a free radical prophylactic produced due to UVB light exposure. ${ }^{9}$

The limitations of this research are that those test animals had varying skin color, and it might affect the result. Therefore, Guinea pigs with similar skin color are suggested for future research. Furthermore, this research does not include a normal control group comprising animals with no exposure and no cream administration. This normal group should help discover the normal amount of melanin pigment and observe the decrease in each group compared to the normal group. Moreover, this research did not measure the quercetin level and the ability of radical scavengers inside corncob extract.

Based on the result, the authors conclude that corncob extract will decrease the amount of melanin in guinea pigs exposed to UVB. The amount of melanin on UVB-exposed and given basic cream groups were $22.8 \pm 0.4$ cells and $18 \pm 0.3$ cells, respectively. Meanwhile, the number of melanin pigment on guinea pigs skin exposed to UVB and given hydroquinone group was $6.3 \pm 3.1$ cells. The ones administered $30 \%$ and $40 \%$ corncob extract were $13.8 \pm 0.2$ cells and $9.4 \pm 0.5$ cells, respectively.

For future research, it is suggested to use animals test with similar skin color, add a normal group (not exposed to UV light and no cream administration), and measure the quercetin level and radical scavenger's ability of corncob extract.

\section{REFERENCES}

1. Hidayat RN. Bawang tiwai (Eleutherine americana) sebagai krim tabir surya mencegah melanogenesis. OISAA Journal of Indonesia Emas 2021; 4(2): 54-58.

2. Layuck ARP, Lintong PM, Loho LL. Pengaruh pemberian air perasan jeruk nipis (Citrus aurantifolia) terhadap jumlah pigmen melanin kulit mencit (Mus musculus) yang dipaparkan sinar matahari. J e-Biomedik 2015 Feb; 3(1).

3. Ahmad Z, Damayanti. Penuaan kulit: patofisiologi dan manifestasi klinis. Berk Ilmu Kesehat Kulit dan Kelamin - Period Dermatology Venereol 2018; 30(03): 208-15.

4. Elinda HR, Muflihunna A. Literature study of corn cob waste utilization as inhibitor reactive oxygen species using 1 , 1-diphenyl-2picrylhydrazil method. Conference book of Online International Conference on Life Sciences (OICLS-20); 2020 Dec: 19-20.

5. Pertiwi NIC, Arijana IK, Linawati NM. Krim ekstrak kulit buah naga super merah mempertahankan kulit tikus wistar (Rattus norvegicus) yang dipapar sinar ultraviolet $\mathrm{B}$. Jurnal medika udayana. 2021; 10(2): 48-54.

6. Murlistyarini S, Hidayah N. Melasma tipe epidermal diterapi dengan injeksi asam traneksamat intradermal serial dan tabir surya. Maj Kesehatan 2019; 6: 67-75.

7. Widowati, Asnan, Sutoyo. Tanaman jagung. Buana Sains. 2016.

8. Saleh LP, Suryanto E, Yudistira A. Aktivitas antioksidan dari ekstrak tongkol jagung (Zea mays L.). Pharmacon 2012; 1(2): 20-4.

9. Kusriani H, Marliani L, Apriliani E. Aktivitas antioksidan dan tabir surya dari tongkol dan rambut jagung (Zea Mays L.). Indones J Pharm Sci Technol 2017 Apr; 13;4(1): 10-7.

10. Siahaan ER, Pangkahila W, Wiraguna AAGP. Krim ekstrak kulit delima merah (Punica granatum) menghambat peningkatan jumlah melanin sama efektifnya dengan krim hidrokuinon pada kulit marmut (Cavia porcellus) betina yang dipapar sinar UVB. J Biomedik 2017; 9(1): 7-13.

11. Kumari S, Thng STG, Verma NK, Gautam HK. Melanogenesis inhibitors. Acta DermatoVenereologica 2018; 98(10): 924-931.

12. Nahhas AF, Abdel-Malek ZA, Kohli I, Braunberger TL, Lim HW, Hamzavi IH. The potential role of antioxidants in mitigating skin hyperpigmentation resulting from ultraviolet and visible light-induced oxidative stress. Photodermatology Photoimmunology and Photomedicine 2019; 35(6): 420-428.

13. Pandel R, Poljšak B, Godic A, Dahmane R. Skin 
photoaging and the role of antioxidants in its prevention. ISRN Dermatol 2013; 1-11.

14. Wulandari SS, Runtuwenw MRJ, Wewengkang DS. Aktivitas perlindungan tabir surya secara in vitro dan in vivo dari krim ekstrak etanol daun soyogik (Saurauia bracteosa DC). Pharmacon 2017; 6(3): 147-56.

15. Wardhani PH. Pilihan terapi hiperpigmentasi pascainflamasi pada kulit berwarna (treatment options for postinflammatory hyperpigmentation in color skin). Berk Ilmu Kesehat Kulit dan Kelamin 2016; 28: 1-8.

16. Astuti DW, Prasetya HR, Irsalina D. Hydroquinone identification in whitening creams sold at minimarkets in minomartini, yogyakarta. J Agromedicine Med Sci 2016; 2(1): 13.
17. Sawant A, Kamath SKH, Kulyadi GP. Solid-inoil-in-water emulsion: an innovative paradigm to improve drug stability and biological activity. AAPS PharmSciTech 2021; 22(5).

18. Maimunah S, Nasution Z, Amila. Pemanfaatan Ekstrak daun Urtica dioica $l$. sebagai anti-aging alami dalam sediaan krim. Jurnal Penelitian 2020; 25(2).

19. Sari AN. Antioksidan alternatif untuk menangkal bahaya radikal bebas pada kulit. J Islam Sci Technol 2015; 1(1): 63-8.

20. Lumempouw LI, Paendong J, Momuat LI, Suryanto E. Potensi antioksidan dari ekstrak etanol tongkol jagung ( Zea mays $L$.). Chemistry Progress 2012; 49-56. 